\title{
Подбор генов-кандидатов для редактирования с целью получения стерильных форм осины (Populus tremula L.)
}

\author{
Сафронычева Е.Д. ${ }^{1,2 *}$, Каржаев Д.С. ${ }^{1,2}$ \\ ${ }^{1}$ Санкт-Петербургский государственный лесотехнический университет имени С.М. Кирова, \\ Санкт-Петербург, Россия \\ ${ }^{2}$ Санкт-Петербургский научно-исследовательский институт лесного хозяйства, \\ Санкт-Петербург, Россия \\ *esafronycheva@mail.ru
}

Ключевые слова: осина, стерильность, гены-мишени, геномное редактирование

Мотивация и цель: В настоящее время исследователи ограничены в проведении экспериментов по получению генно-модифицированных растений древесных пород, так как присутствует опасность попадания их пыльцы или семян в окружающую среду. Это может повлечь за собой необратимые изменения в биоценозах и даже целых экосистемах. Таким образом, стерильность является необходимым условием для выращивания модифицированных растений в условиях открытого грунта. Для получения экологически безопасных клонов древесных пород с измененным геномом в качестве модельного объекта была выбрана осина (Populus tremula L.), так как на территории РФ этот вид Populus является преобладающим.

Meтоды и алгоритмы: На первом этапе редактирования необходимо определить целевой ген, который будет подвергаться изменениям. Согласно литературным данным, ключевую роль в развитии генеративной сферы у осины играют гены Leafy и Agamous. Согласно теории 'ABCDE' формирования цветка, первый способствует появлению генеративной почки вместо вегетативной, а второй отвечает за формирование пестиков и тычинок в цветке. При повреждении гена Leafy на месте цветка появляется обычный побег, при неправильной работе гена Agamous на месте пестиков и тычинок формируются чашелистики.

Результаты: В ходе работ были отобраны целевые гены для последующего редактирования с целью получения стерильных особей осины (Populus tremula L.). Разработаны праймеры, позволяющие амплифицировать первый экзон каждого из этих генов. Полученные продукты ПЦР были секвенированы по Сэнгеру. Сравнение полученных последовательностей с референсной ДНК показало полное их соответствие первым экзонам отобранных генов.

Заключение $u$ доступность: Полученные результаты позволяют перейти к следующему этапу процедуры получения стерильных форм осины с использованием технологии CRISPR-Cas9.

Благодарности: Исследование выполнено в рамках государственного задания СПбНИИЛХ № 053-00012-21-00 от 22.12.2020. 